\title{
Microbial diversity and community structure in Fynbos soil
}

\author{
ETIENNE SLABBERT,* RAPHAEL Y. KONGOR,† KAREN J. ESLER†, $\ddagger$ and KARIN JACOBS* \\ *Department of Microbiology, Stellenbosch University, Private Bag X1, Matieland, 7600, South Africa, +Department of \\ Conservation Ecology and Entomology, Stellenbosch University, Private Bag X1, Matieland, 7600, South Africa, ‡Centre for \\ Invasion Biology, Stellenbosch University, Private Bag X1, Matieland, 7600, South Africa
}

\begin{abstract}
The Fynbos biome in South Africa is renowned for its high plant diversity and the conservation of this area is particularly important for the region. This is especially true in the case of endangered vegetation types on the lowlands such as Sand Fynbos, of which only small fragments remain. The question is thus whether the diversity of the aboveground flora is mirrored in the below-ground microbial communities. In order to determine the relationship of the above- and below-ground communities, the soil community composition of both fungal and bacterial groups in Sand Fynbos was characterized over space and time. A molecular approach was used based on the isolation of total soil genomic DNA and automated ribosomal intergenic spacer analysis of bacterial and fungal communities. Soil from four different sites was compared to resolve the microbial diversity of eubacterial and fungal groups on a local (alpha diversity) scale as well as a landscape scale (beta diversity). The community structures from different sites were compared and found to exhibit strong spatial patterns which remained stable over time. The plant community data were compared with the fungal and the bacterial communities. We concluded that the microbial communities in the Sand Fynbos are highly diverse and closely linked to the above-ground floral communities.
\end{abstract}

Keywords: 16S rDNA, 18S rDNA, bacteria diversity, bacterial communities, fungal communities, fungal diversity, fynbos soil

Received 22 July 2009; revision accepted 8 December 2009

\section{Introduction}

The Cape Floristic Region falls within an area recognized as one of the world's biodiversity hotspots (Cowling et al. 2003). Within the region, Sand Fynbos is among the most poorly conserved of all vegetation types in South Africa and has been classified as endangered (Cowling 1992; Rouget et al. 2006). Approximately $95 \%$ of this vegetation type has been transformed into agricultural land, invaded by alien species or developed (Low \& Rebelo 1996; Rebelo et al. 2006). The result is the fragmentation of the vegetation which now only occurs in isolated pockets (Rebelo 1992; Heijnis et al. 1999). Plant studies have shown that in Fynbos areas, fragments have significantly fewer plant species than

Correspondence: Etienne Slabbert, Fax: +27 21808 5807;

E-mail: 13265695@sun.ac.za areas of the same size located inside a more extensive pristine area (Bond et al. 1984; Kemper et al. 1999; Kongor 2009). Smaller land fragments are also more adversely affected by outside factors compared to larger areas. The effect and significance of fragmentation on microbial populations, particularly the beta diversity, has thus far not been considered (Lozupone \& Knight 2007).

The soil environment harbours a large proportion of the earth's undiscovered biodiversity. The diversity of soil micro-organisms is not as well studied and it is believed that only about $1 \%$ of the organisms that occurs in soil have been cultured, identified, and characterized (Torsvik et al. 1990; Hawksworth 2001). Studying the diversity in different ecosystems contributed to the understanding of the extent of microbial diversity (Jessup et al. 2004; Bertin et al. 2008; Zhou et al. 2008). The exact factors that are responsible for diversity and 
community patterns are, however, not well understood (Zhou et al. 2002).

The general factors that influence microbial populations are the soil properties, which may be physical or chemical. Physical properties include soil moisture, aeration, texture, structure and temperature (Gaur \& Misra 1978; Fomsgaard \& Kristensen 1999; Chen et al. 2007). Chemical properties include nutrient characteristics and pH (Gaur \& Misra 1978; Jonasson et al. 1999; Lipson et al. 1999; Turrión et al. 2002). The above-ground vegetation structure and makeup also have an influence on the microbial population within the soil (Nüsslein \& Tiedje 1999; Hamilton \& Frank 2001; Tangjang et al. 2009). The relationship between microbes and the above-ground vegetation, specifically in Fynbos, has been focused on in one previous study (Stafford et al. 2005).

The diversity and variation of soil micro-organisms have been studied in a number of different ecosystems (Saetre \& Baath 2000; Bhatnagar \& Bhatnagar 2005; Bezemer et al. 2006). This includes studies which looked at soil microbial diversity at a landscape scale and mesoscale (Green et al. 2004). Many of these studies were, however, only focused on the rhizosphere communities or diversity of mycorrhizal fungi (Allsopp \& Stock 1995; Caravaca et al. 2002; Bergero et al. 2003; Spriggs et al. 2003). The beta diversity of plants in the Fynbos biome is characteristically high (Cowling 1992). This high species turnover results in a significant variation in the plant community diversity and composition between sites. Thus, we believe that this species turnover may also drive variations in the microbial communities between different locations. In this study aboveground plant diversity, microbial community structure, and relative diversity of fungal and eubacterial groups were investigated and compared in four Atlantis Sand Fynbos fragments.

\section{Materials and methods}

\section{Study area}

The sites at Pella and Riverlands are part of a conservation area administered by CapeNature. The site at Kalbaskraal is in the process of being rehabilitated from Port Jackson (Acacia saligna) infestation after its introduction to stabilize the sandy soil. The site at Camphill Village is surrounded by farmland with no planned or natural fires having occurred for 40 years and we thus consider this to be a neglected site. The soil type observed in Atlantis Sand Fynbos is acidic tertiary grey regic sand (Goldblatt \& Manning 2000) derived originally from Cambrian Cape Granite (Rebelo et al. 2006) and with Aeolian origin. The soils of the study sites are all on average $2 \mathrm{~m}$ in depth (Deacon et al. 1983; Rebelo
1996) with a $\mathrm{pH}$ that ranges from 3.6 to 4.7 (Low 1983). The soil typically has an organic matter content of between $1-3 \%$ and available carbon content of less than 1\% (Low 1983; Mitchell et al. 1984). The soil of the study areas are low in nutrients and are especially poor in phosphorus (Kruger 1979; Richards et al. 1997). This is due to the low amounts of $\mathrm{P}_{2} \mathrm{O}_{5}$ found in the parental palaeozoic rocks, sandstones, shales, schists and granites, which are typically below 1\% (Marchant \& Moore 1978; Low \& Bristow 1983).

\section{Sampling}

Soil samples were taken at four different sites in the Atlantis Sand Fynbos vegetation type (Western Cape, South Africa) (Mucina \& Rutherford 2006). The study sites were located between 160 and $220 \mathrm{~m}$ above sea level and sloped slightly between $0 \%$ and $4 \%$ (Witkowski \& Mitchell 1987). The sites were located at Riverlands (1100 ha), Pella (600 ha), Kalbaskraal (37 ha) and Camphill Village (16 ha) (Fig. 1, Table 1). On every site, three random plots of $10 \mathrm{~m} \times 10 \mathrm{~m}$ were identified. The plots were selected and divided in four quadrants. Ten soil samples were taken randomly in each quadrant within the first $10 \mathrm{~cm}$ of the surface away from plant to avoid roots. The 10 samples of $50 \mathrm{~g}$ each were homogenized and sieved using a 2-mm mesh sieve to remove plant debris and produce a composite sample for each quadrant (Coutinho et al. 1999). Sampling was conducted in February (Summer), March (Autumn), July (Winter) and September (Spring) 2007 to acquire representative samples for each season.

The above-ground plant species inventory was carried out between September and December of 2004 and 2005. During the period between 2005 and 2007, the vegetation was unlikely to change, since no fire events occurred during this period. The inventory was conducted using a $50 \mathrm{~m} \times 20 \mathrm{~m}$ modified Whittaker plot design (Stohlgren et al. 1995). The $50 \mathrm{~m} \times 20 \mathrm{~m}$ plots had $0.1 \mathrm{~m}^{2}$, ten $1 \mathrm{~m}^{2}$, three $5 \mathrm{~m}^{2}$ and three $100 \mathrm{~m}^{2}$ subplots. In each sub-plot, presence-absence data of plant taxa were recorded. The data of the $10 \mathrm{~m} \times 10 \mathrm{~m}$ plots were used for comparison with below-ground communities.

\section{DNA extraction and PCR amplification}

DNA was extracted from $0.35 \mathrm{~g}$ of soil within $12 \mathrm{~h}$ of sampling using the ZR Soil Microbe DNA kit (Zymo Research) and the presence of genomic DNA was checked on a $1 \%$ agarose gel, stained with ethidium bromide. PCR reactions were performed on the genomic DNA using fungal and eubacterial primers sets to evaluate its application in automated ribosomal internal transcribed spacer (ITS) analysis (ARISA). Eubacterial 


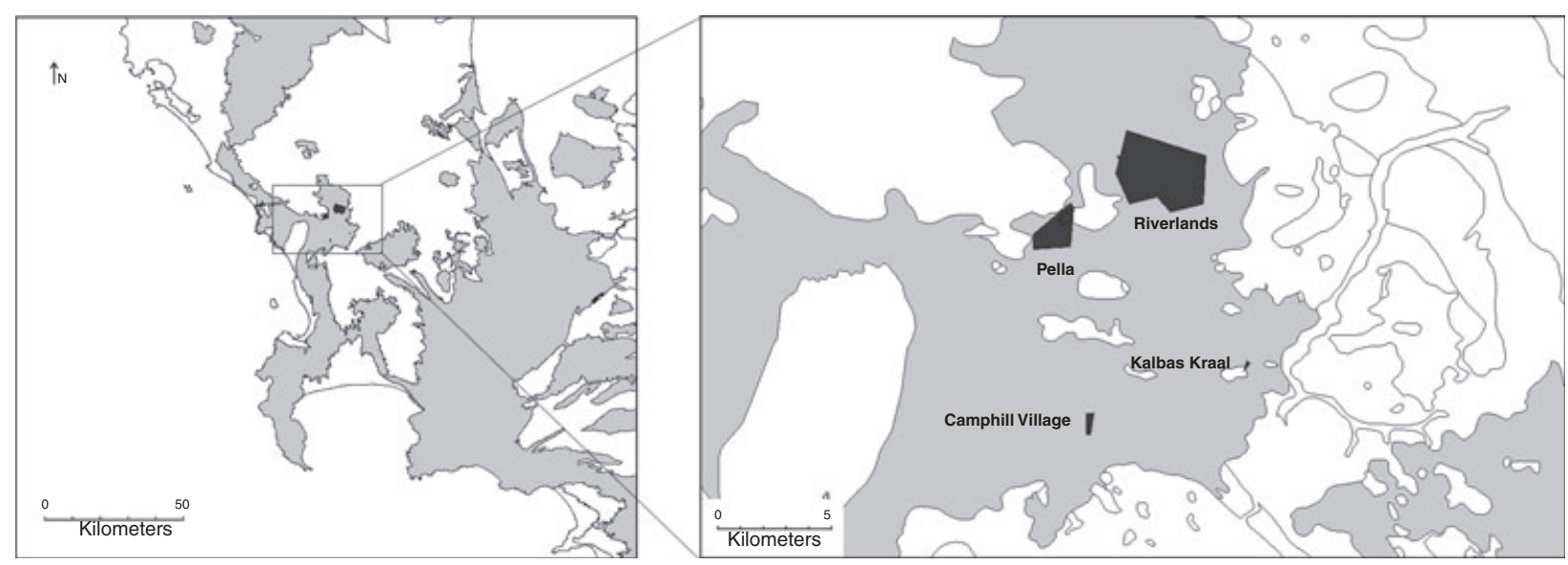

Fig. 1 Location of the study sites within the Sand Fynbos.

Table 1 Location of the study plots

\begin{tabular}{ll}
\hline Site & Location of site (GPS) \\
\hline Pella & \\
Plot 1 & $\mathrm{S} 33^{\circ}, 51022 \mathrm{E} 18^{\circ}, 55236$ \\
Plot 2 & $\mathrm{S} 33^{\circ}, 50960 \mathrm{E} 18^{\circ}, 54925$ \\
Plot 3 & $\mathrm{S} 33^{\circ}, 52011 \mathrm{E} 18^{\circ}, 54766$ \\
Riverlands & \\
Plot 1 & $\mathrm{S} 33^{\circ}, 49795 \mathrm{E} 18^{\circ}, 58931$ \\
Plot 2 & $\mathrm{S} 33^{\circ}, 49788 \mathrm{E} 18^{\circ}, 58608$ \\
Plot 3 & $\mathrm{S} 33^{\circ}, 49608 \mathrm{E} 18^{\circ}, 58388$ \\
Camphill Village & \\
Plot 1 & $\mathrm{S} 33^{\circ}, 59701 \mathrm{E} 18^{\circ}, 56554$ \\
Plot 2 & $\mathrm{S} 33^{\circ}, 59787 \mathrm{E} 18^{\circ}, 56433$ \\
Plot 3 & $\mathrm{S} 33^{\circ}, 59774 \mathrm{E} 18^{\circ}, 56327$ \\
Kalbas Kraal & \\
Plot 1 & $\mathrm{S} 33^{\circ}, 57061 \mathrm{E} 18^{\circ}, 62861$ \\
Plot 2 & $\mathrm{S} 33^{\circ}, 57133 \mathrm{E} 18^{\circ}, 62773$ \\
\hline &
\end{tabular}

specific primers, ITSReub and FAM (carboxy-fluorescein) labelled ITSF, were used to determined bacterial diversity using ARISA (Cardinale et al. 2004). The fungal diversity was determined by using fungal primers ITS4 and FAM labelled ITS5 (White et al. 1990) in the PCR reactions. PCR reactions were done using a GeneAmp PCR System 2400 (Applied Biosystems). The reaction mixture contained $0.5 \mu \mathrm{L}$ of the purified genomic DNA extracted from soil, $500 \mathrm{nM}$ of each primer and $5 \mu \mathrm{L}$ of $2 \times$ KapaTaq Readymix (KapaBiosystems, South Africa) in a total volume of $10 \mu \mathrm{L}$. The PCR conditions consisted of an initial denaturing step of $3 \mathrm{~min}$ at $95{ }^{\circ} \mathrm{C}$ followed by 40 cycles of $95{ }^{\circ} \mathrm{C}$, for $30 \mathrm{~s}, 51^{\circ} \mathrm{C}$ for $30 \mathrm{~s}$ and $72{ }^{\circ} \mathrm{C}$ for $30 \mathrm{~s}$. The reaction was completed with a final extension at $72{ }^{\circ} \mathrm{C}$ for $5 \mathrm{~min}$ and then cooled and held at $4{ }^{\circ} \mathrm{C}$. PCR for each sample was performed in triplicate and pooled to eliminate background noise and reduce the PCR variability occurring. PCR samples were separated on a $1 \%$ agarose gel, stained with ethidium bromide and visualized using ultraviolet light.

\section{Automated ribosomal intergenic spaceranalysis}

The PCR products were run on an ABI 3010xl Genetic analyser to obtain an electropherogram of the different fragment lengths and fluorescent intensities. F-ARISA PCR samples were run along with LIZZ 600 size standard which contained sizes from 60 to $660 \mathrm{bp}$ in length. B-ARISA samples were run with ROX 1.1 size standard which varied from 20 to $900 \mathrm{bp}$ (Slabbert 2008). ARISA data was analysed using Genemapper 4.1 software. The software converted fluorescence data to an electropherogram and the peaks which represented fragments of different sizes are termed operational taxonomic units (OTU). Only fragment sizes larger than $0.5 \%$ of the total fluorescence ranging from 100 to 1000 base pairs in length was considered for analysis. A bin size of $3 \mathrm{bp}$ for fragments below $700 \mathrm{bp}$ and $5 \mathrm{bp}$ for fragments above $700 \mathrm{bp}$ was employed to minimize the inaccuracies in the ARISA profiles (Brown et al. 2005).

\section{Data analysis}

Species accumulation curves were plotted for fungi and bacteria for each of the four sampling events during the year. The fungal and bacterial data sets used were randomized by re-sampling the data (10 times) using Poptools 2.7 software and transformed to $100 \%$ of the maximum value. Twelve species-accumulation models commonly used were evaluated against the species accumulation curves for both bacteria and fungi using Statistica 8 (Statsoft 2008). The estimation methods used included Chao (based on presence and absence data), 
1st order Jack-knife, Bootstrap and Michaelis-Menten models. The various estimators appear to perform differently depending on the system (Colwell \& Coddington 1995). The suitability of the richness estimators was evaluated according to Bartels \& Nelson (2006).

The peak heights were used to calculate the diversity indices for each ARISA profile using Microsoft Excel ${ }^{\mathrm{TM}}$ software. The Shannon $\left(\mathrm{H}^{\prime}\right)$ index was calculated for each sample and each plot to determine the disorder in the species distribution of the community. The increase of beta diversity was determined over the different samples, plots and sites. The Whittaker $(\beta w)$ index for beta diversity was determined over all scales and comparisons made between samplings (Whittaker 1972; Mena \& Vázquez-Domínguez 2005).

The Whittaker similarity index was calculated for bacterial and fungal profile data between all plots. The distance relationship between the samples was illustrated by performing a complete linkage cluster analyses using the Whittaker ( $\mathrm{Sw}$ ) similarity indices (Hewson et al. 2006). After initial grouping with cluster analysis, the significance of the groupings were tested by performing a non-parametric analysis of similarity analysis (ANOSIM) with 10000 permutations (Clarke 1993).

The vegetation data were expressed as a data matrix based on the presence or absence of a specific plant species in the plot. Fynbos communities at the different sites were compared by calculating the Jaccard's similarity index (Jaccard 1912). The relationship between the bacterial and fungal community similarity data and the plant community similarity was tested by using a nonparametric partial Mantle test (Sokal \& Rohlf 1981). The partial mantel test was performed using ZT-software with a confidence level of $95 \%$ (Bonnet \& Van der Peer 2002).

\section{Results}

\section{DNA extraction and ARISA-PCR}

Genomic DNA extractions from soil from different sites resulted in consistent yields of more than $100 \mathrm{ng} / \mu \mathrm{L}$

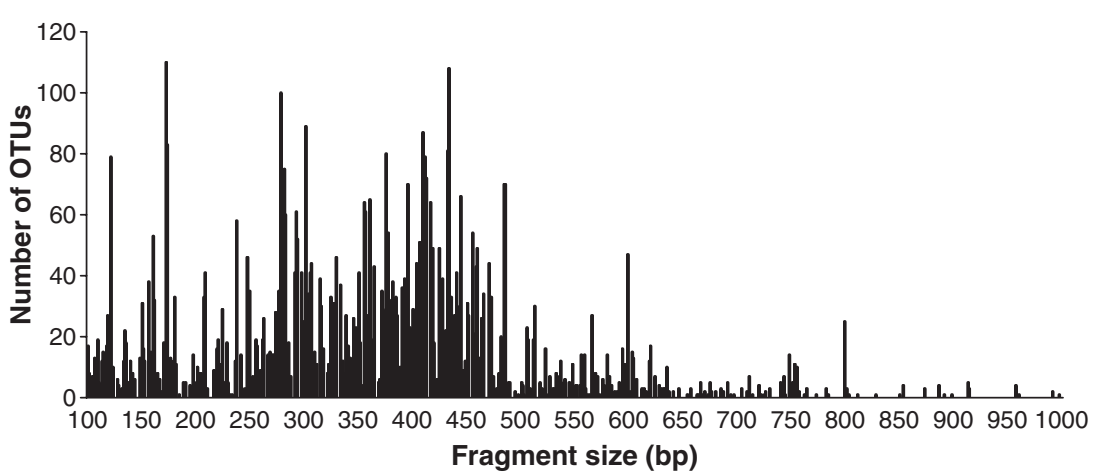

(Fig. S1). PCR reactions resulted in smears ranging from 100 to $900 \mathrm{bp}$ with bacterial primers and 150 to $800 \mathrm{bp}$ with fungal primers (Figs S2 and S3). Bacterial ARISA electropherogram data produced peaks from 100 to $900 \mathrm{bp}$ as extrapolated by Genemapper from the ROX 1.1 size standard. The fungal ARISA electropherogram results show peaks ranging from 150 to $800 \mathrm{bp}$ as extrapolated using the LIZZ 600 size standard. Genemapper detected approximately 150 unique peaks for F-ARISA and 250 for B-ARISA in all the samples.

\section{Frequency of bacterial and fungal OTUs}

Bacterial ARISA demonstrate a dominance of fragments between 150 and $500 \mathrm{bp}$ in length for the bacterial population (Fig. 2). This size category constitutes $90.6 \%$ of the total operational taxonomic units observed. The size data based on the frequency of fungal OTUs indicate the dominance of peak heights between $550 \mathrm{bp}$ and about $650 \mathrm{bp}$ (Fig. 3). This region of the histogram constitutes $45.6 \%$ of the total number of peaks observed.

\section{Below-ground richness and diversity}

The number of bacterial OTUs remained significantly higher than fungal OTUs across all plots, and this observation was consistent from February to September (Fig. S4). The number of bacterial OTUs in each sample in February ranged from 42 to 68 , in April from 40 to 56, in June from 40 to 51 and in September from 43 to 49. The number of unique fungal OTUs in each sample was consistently less than the number of bacterial OTUs, and varied between 12 and 34 in February, from 21 to 37 in April, from 21 to 35 in June and from 27 to 36 in September.

Due to the relatively high species number, the bacterial diversity is expected to be higher than the fungal diversity. The Shannon index for the bacterial communities remained very high $\left(H^{\prime}=3.60-4.4\right)$ throughout the year (Fig. S5). The lowest fungal diversity was detected at Kalbaskraal $\left(H^{\prime}=2.9\right)$, and the highest $\left(H^{\prime}=4.3\right)$ at Riverlands during the same sampling time

Fig. 2 Summary of the number of bacterial operational taxonomic units detected of each size category. 


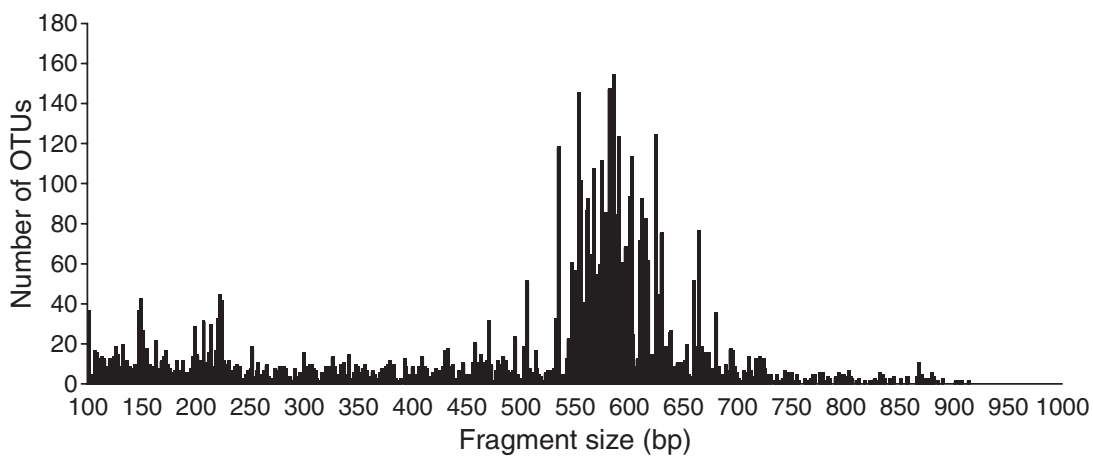

Fig. 3 Summary of the number of fungal operational taxonomic units detected for each size category. in February 2007 (Fig. S5). Although diversity indices varied spatially and over time, no significant differences between sites were observed.

\section{Below-ground species accumulation and estimation}

The parametric Beta-P models showed a consistent good fit for bacterial accumulation curves over all four sampling dates (Fig. S6). In addition to the Beta-P, the three parametric Weibull models also showed significant fit with fungal accumulation data. It is apparent from the fungal species accumulation curves that the number of fungal species is still increasing relatively fast compared to the bacterial equivalents (Fig. S7). The Bootstrap method performed better than the other species estimation models tested. The results predicted a detection level of around 90-92.6\% for bacterial species (Table 3) and around $87.5 \%$ for fungi (Table 4 ) using ARISA.

\section{Below-ground community structure}

The cluster analysis performed illustrated the relationship between the intra-fungal and bacterial communities according to occurrence and abundance of operational taxonomic units. The tree diagrams for bacteria and fungal communities display high similarities between plots from the same sites (Figs. 4 and 5).

\section{Below-ground beta diversity}

The beta diversity of bacterial and fungal samples is very high, with values above 4.0 observed except for the bacterial samples in the month of September when it only reached 3.6 (Table 2). The beta diversity of both the fungal and bacterial communities decreased with an increase in scale due to the increase likelihood of species-overlap occurring. The comparative beta diversity for fungi is significantly higher at larger scales during each sampling event. Locally occurring microbial species also represent relatively unique communities.
Table 2 Summary of the Whittaker beta diversity index over the three area sizes considered

\begin{tabular}{llll}
\hline & \multicolumn{2}{l}{ Whittaker (Bw) } & \\
\cline { 2 - 3 } & Sample & Plot & Site \\
\hline Bacteria & & & \\
$\quad$ February & 5.0965 & 1.7154 & 0.67683 \\
April & 4.0091 & 1.3848 & 0.43928 \\
June & 4.8353 & 1.6719 & 0.68521 \\
$\quad$ September & 3.6056 & 1.543 & 0.67315 \\
Fungi & & & \\
$\quad$ February & 5.647 & 2.1989 & 1.1232 \\
April & 5.0414 & 2.2043 & 1.0892 \\
June & 4.7284 & 1.7455 & 0.85542 \\
September & 4.8423 & 1.9685 & 0.87013 \\
\hline
\end{tabular}

\section{Relationship between plant and microbial communities}

The partial Mantel test showed a strong, to very strong correlation between the bacterial and the plant community absence and presence data. This indicates a link between the occurrences of some bacterial species with the presence of certain plant species. The high beta diversity of above-ground plant species can thus be expected to directly influence the diversity of soil bacteria (Table 5). The fungal community showed a strong relationship between plant presence and absence data when performing the Mantel test. When controlling for the influence of space, this relationship becomes insignificant.

Where above-ground plant species diversity varied greatly, large variations in the microbial soil communities was also shown. The above-ground community composition changed very little during the entire year of soil sampling. Bacterial communities correlated better with the plant communities and fungal community structure appeared to be linked to spatial regression. The species accumulation characteristics categorize these fungal communities as having a high risk of local extinction. 
Table 3 The performances of the Bootstrap model based on half the number individuals sampled, the estimated number of species and the percentage of the estimate observed with ARISA

\begin{tabular}{|c|c|c|c|c|c|c|}
\hline & \multicolumn{6}{|l|}{ Bacteria } \\
\hline & $\begin{array}{l}\text { Number of } \\
\text { samples used }\end{array}$ & Model & $\begin{array}{l}\text { Number } \\
\text { observed }\end{array}$ & $\begin{array}{l}\text { Estimation using } \\
\text { half the individuals }\end{array}$ & $\begin{array}{l}\text { Estimate number } \\
\text { of species }\end{array}$ & $\begin{array}{l}\text { Percentage observed } \\
\text { with ARISA }\end{array}$ \\
\hline February & 21 & Bootstrap & 276 & 275.03 & 306 & 90.19608 \\
\hline April & 25 & Bootstrap & 240 & 242 & 259 & 92.66409 \\
\hline June & 23 & Bootstrap & 265 & 259 & 290 & 91.37931 \\
\hline September & 23 & Bootstrap & 215 & 214 & 239 & 89.95816 \\
\hline
\end{tabular}

Table 4 The performances of the Bootstrap model based on half the number individuals sampled, the estimated number of species and the percentage of the estimate observed with ARISA

\begin{tabular}{lllllll}
\hline & \multicolumn{2}{l}{ Fungi } & & & & \\
\cline { 2 - 6 } & $\begin{array}{l}\text { Number of } \\
\text { samples used }\end{array}$ & Model & $\begin{array}{l}\text { Number } \\
\text { observed }\end{array}$ & $\begin{array}{l}\text { Estimation using } \\
\text { half the individuals }\end{array}$ & $\begin{array}{l}\text { Estimate number } \\
\text { of species }\end{array}$ & $\begin{array}{l}\text { Percentage observed } \\
\text { with ARISA }\end{array}$ \\
\hline February & 18 & Bootstrap & 179 & 168 & 205 & 87.31707 \\
April & 24 & Bootstrap & 164 & 163.75 & 188 & 87.23404 \\
June & 19 & Bootstrap & 154 & 145 & 176 & 87.5 \\
September & 23 & Bootstrap & 180 & 177 & 205 & 87.80488 \\
\hline
\end{tabular}

\section{Discussion}

In this study we successfully used ARISA to characterize the microbial communities in the soil of the Sand Fynbos. The data obtained could effectively be used to analyse and compare ecological information. Previous studies have shown ARISA to be a reproducible and extremely sensitive technique for assessing microbial community structure (Fisher \& Triplett 1999; Green et al. 2004; Torzilli et al. 2006). The supporting data from above-ground ecological studies provide considerable insight into soil microbial diversity in the Fynbos ecosystem which was previously unexplored.

PCR reactions with universal eubacterial primers resulted in an abundance of shorter fragments that most likely represent gram-positive bacteria. As most grampositive bacteria have no tRNA in the spacer region which would results in shorter fragment lengths (Gürtler \& Stanisich 1996). This would be expected due to the well-recognized dominance of gram-positive bacterial species in soil (Torsvik et al. 1990; Dunbar et al. 2002; Smalla et al. 2001). Similarly, the dominance of fragments between 550 and 650 bp observed with F-ARISA are expected and previous studies also report similar fragments in soil (Cardinale et al. 2004).

ARISA has been shown to be relatively sensitive in the detection of low frequency templates in mixed samples (Danovaro et al. 2006). This sensitivity is evident in the accumulation curves, which shows that the numbers of unique fungal OTUs are still increasing relatively rapidly with the addition of new samples compared to the bacterial equivalents. The relatively steep increase towards the tail of the curve is an indication of the presence of high numbers of low frequency fungal OTUs (Ugland et al. 2003). High beta diversity and subsequent heterogeneity in the fungal communities is demonstrated by the accumulation curve that is less steep compared to the bacterial accumulation curve. This would imply that bacteria are more evenly distributed throughout the soil than fungi. The species accumulation characteristics categorize these fungal communities as having a high risk of local extinction compared to bacteria. To determine the estimated number of taxa in the area, non-parametric methods were shown to be more accurate (Chazdon et al. 1998). Different methods have been shown to be effective for specific applications and specific niches (Bartels \& Nelson 2006), but the Bootstrap method proved most useful in estimating total soil microbial OTUs in this study (Tables 3 and 4).

The diversity indices varied spatially and over time, but there were no significant differences between sites. Although the diversity between the plots in most cases did not differ considerably, the peak composition of the ARISA profiles differed significantly as indicated by the Whittaker similarity indices (Figs. 4 and 5). The higher 

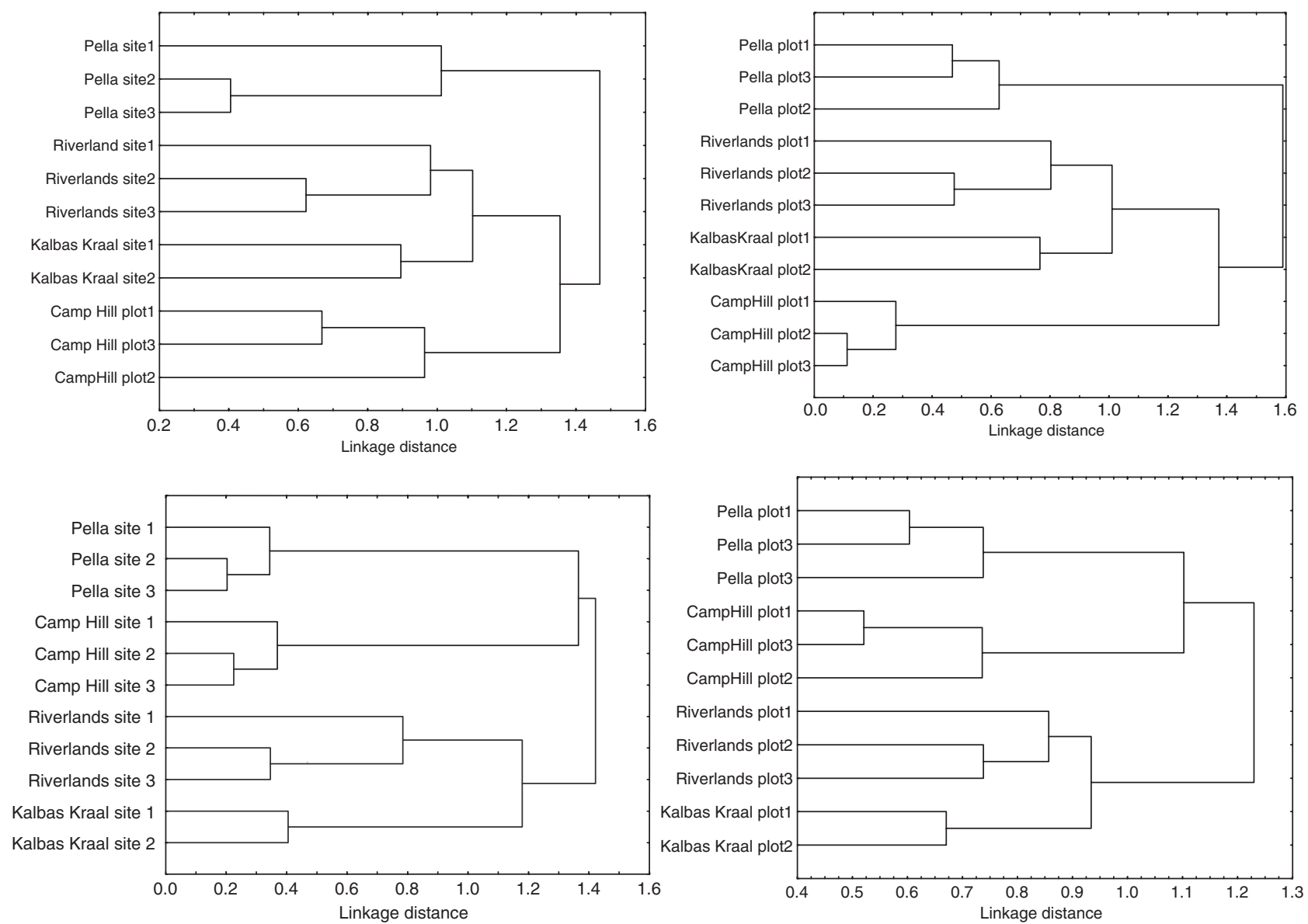

Fig. 4 Tree diagrams of the Cluster analysis of the Whitaker similarity analysis for the bacterial OTUs during February 2007.

similarity between bacteria and fungal communities from the same sites is expected when considering that a decline in similarity over distance is known to occur between communities (Green et al. 2004; Ramette \& Tiedje 2006; Peay et al. 2007). The similarities between plots remained constant for both bacterial and fungal OTUs over all four sample events. The distribution of microbial communities was shown not to be random and strong spatial patterns exist with relatively stable fungal and bacterial communities (Figs. 4 and 5). Over short time scales, Fynbos plant community composition changes very little from season to season, unless impacted by fire (Cowling et al. 1997). As there was not a fire event during the study period, the above-ground community composition changed very little during the entire year. This stability in community composition is mimicked by the microbial communities, suggesting a relationship between the above and below-ground communities.

It is well recognized that the primary factor influencing Fynbos diversity is not its alpha diversity at a specific site but the beta diversity (Cowling 1992). The beta diversity of both the fungal and bacterial communities decreased with an increase in scale due to the increase likelihood of species-overlap occurring (Table 2). The spatial separation between sites and the scale at which beta diversity is observed proved to be important factors when looking at the beta diversity of bacteria and fungi in the Sand Fynbos. The exact extent of microbial diversity in a system is not only a measure of local diversity, but also beta diversity is an important factor when considering the overall diversity of an ecosystem. The particular species turnover demonstrated by the ARISA profiles is an important primary factor contributing to the diversity of fungal and bacterial species of the Sand Fynbos. The large species turnover seen in Fynbos is of vital importance when considering the conservation of Fynbos (Cowling 1992; Rouget et al. 2003). Locally existing microbial species also represent unique communities. The fungal community has significantly higher beta diversity, even though dispersal by aerial spores poses less of a limitation to dispersal than is the case of bacteria (Unterseher \& Tal 2006). The high beta diversity, which is the main contributing factor to the high biodiversity seen in Fynbos (Cowling et al. 2003; Kongor 2009), appears to play an important role in the 

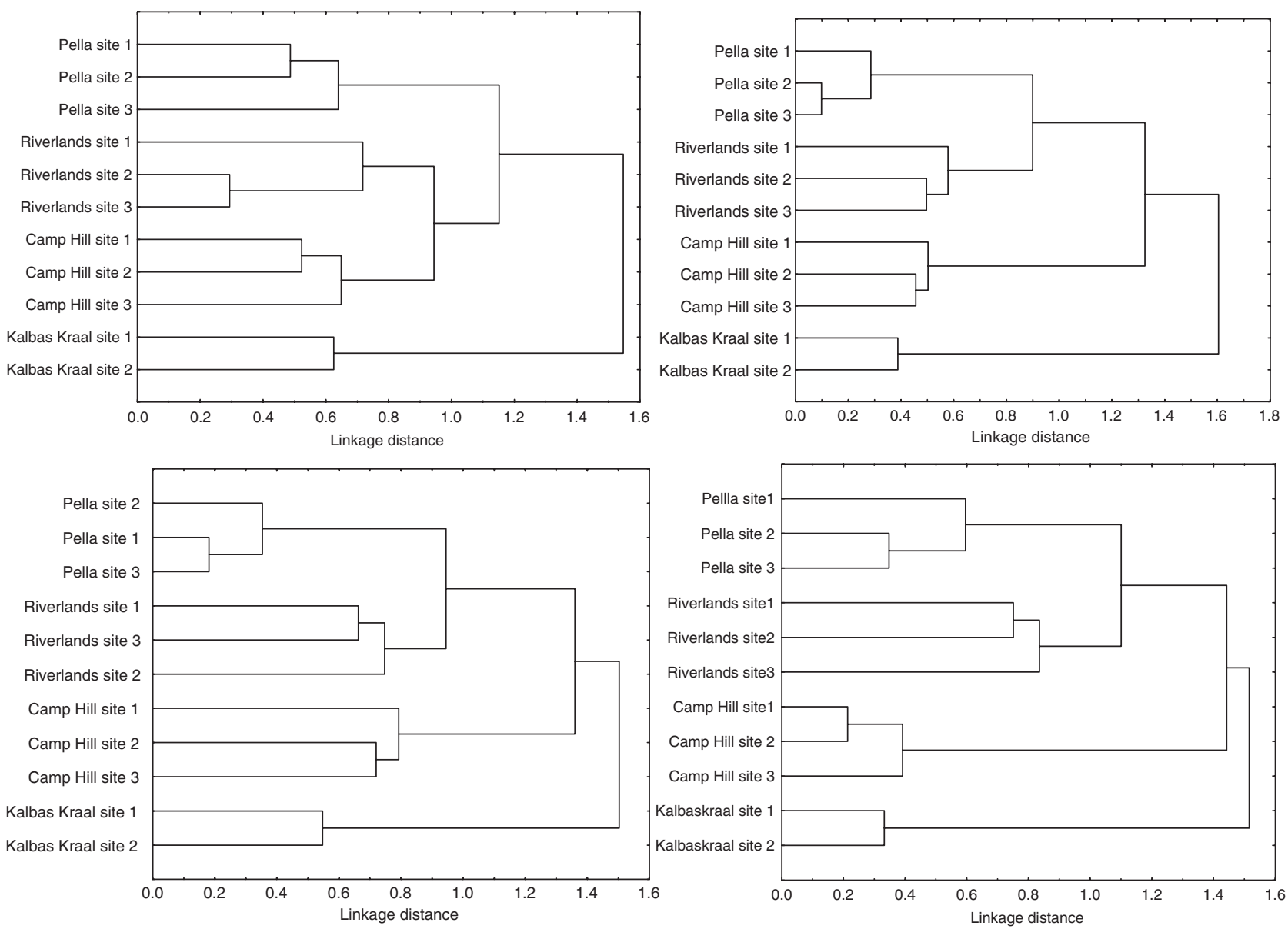

Fig. 5 Tree diagrams of the Cluster analysis of the Whitaker similarity analysis for the fungal OTUs during February 2007.

Table 5 Results for the Mantel test and partial Mantel test

\begin{tabular}{|c|c|c|c|c|}
\hline & \multicolumn{2}{|l|}{ Fungi } & \multicolumn{2}{|l|}{ Bacteria } \\
\hline & $\begin{array}{l}\text { Mantel } \\
\text { test }\end{array}$ & $\begin{array}{l}\text { Partial } \\
\text { Mantel test }\end{array}$ & $\begin{array}{l}\text { Mantel } \\
\text { test }\end{array}$ & $\begin{array}{l}\text { Partial } \\
\text { Mantel test }\end{array}$ \\
\hline February 2007 & 0.706 & 0.212 & 0.59 & 0.6 \\
\hline April 2007 & 0.442 & 0.112 & 0.37 & 0.62 \\
\hline June 2007 & 0.398 & 0.091 & 0.24 & 0.57 \\
\hline September 2007 & 0.659 & 0.124 & 0.11 & 0.49 \\
\hline
\end{tabular}

biodiversity of bacterial and especially the fungal communities.

The results from the Partial Mantel tests indicate that bacterial community structure is closely linked to plant communities, although it follows a similar clustering pattern to the fungal communities during all four sampling dates. The higher similarities between sites on the larger fragments, Pella and Riverlands, are indicative of a community structure which lends itself to spatial patterning (Peay et al. 2007). A link between the occurrence of some bacterial OTUs with the presence of certain plant species was suggested. Thus, the high beta diversity of above-ground plant species is expected to influence the diversity of soil bacteria (Table 5).

From the data it is apparent that a correlation between plant and microbial communities exists although the exact causes of the relationship remains unclear. A few possibilities may explain the link between plants and micro-organisms. First, it is possible that both the plant and the microbial populations have an effect on the abiotic environment and on each other (Reynolds et al. 2003; Ehrenfeld et al. 2005; Hättenschwiler et al. 2005). A second possibility is that the same prevailing soil and environmental conditions that affect the above-ground species composition affect the microbial population structure and the two do not affect each other to a very high degree (Cornelissen et al. 2003; Ramette \& Tiedje 2006). Finally, it is possible that a oneway interaction between the plant communities and the soil micro-organisms exists, where the plant litter is the main contributing factor and driver of the microbial community structure (Xiao \& Zheng 2001; Liu et al. 2005). The effect of above-ground spatial distribution on 
microbial communities can, therefore, not be discounted and seems to play a bigger role in the fungal communities than in the bacterial communities.

\section{Acknowledgements}

We owe special gratitude to the German Federal Ministry for Education and Science for funding the plant diversity section of this study through BIOTA Southern Africa project (Promotion numbers 01 LC 0024A and 01 LC 0624A2) and the National Research Foundation (NRF) for funding the microbial diversity section of the study. We would like to acknowledge CapeNature and all the landowners for allowing access to their property.

\section{References}

Allsopp N, Stock WD (1995) Relationships between seed reserves, seedling growth and mycorrhizal responses in 14 related shrubs (Rosidae) from a low-nutrient environment. Functional Ecology, 9, 248-254.

Bartels PJ, Nelson DR (2006) A large-scale, multihabitat inventory of the Phylum Tardigrada in the Great Smoky Mountains National Park, USA: A preliminary report. Hydrobiologia, 558, 111-118.

Bergero R, Girlanda M, Bello F, Luppi AM, Perotto S (2003) Soil persistence and biodiversity of ericoid mycorrhizal fungi in the absence of the host plant in a Mediterranean ecosystem. Mycorrhiza, 13, 69-75.

Bertin PN, Médigue C, Normand P (2008) Advances in environmental genomics: towards an integrated view of micro-organisms and ecosystems. Microbiology, 154, 347-359.

Bezemer TM, Lawson CS, Hedlund K, Edwards AS, Brooks AJ, Igual JM, Mortimer SR, Van der Putten WH (2006) Plant species and functional group effects on abiotic and microbial soil properties and plant-soil feedback responses in two grasslands. Journal of Ecology, 94, 893-904.

Bhatnagar A, Bhatnagar M (2005) Microbial diversity in desert ecosystems. Current Science, 89, 91-100.

Bond WJ, Midgley J, Vlok J (1984) When is an island not an island? Insular effects and their causes in fynbos shrublands. Oecologia, 77, 515-521.

Bonnet E, Van de Peer Y (2002) Zt: a software tool for simple and partial Mantel tests. Journal of Statistical Software, 7, 1-12.

Brown MV, Schwalbach MS, Hewson I, Fuhrman JA (2005) Coupling 16S-ITS rDNA clone libraries and ARISA to show marine microbial diversity; development and application to a time series. Environmental Microbiology, 7, 1466-1479.

Caravaca F, Barea JM, Roldán A (2002) Synergistic influence of an arbuscular mycorrhizal fungus and organic amendment on Pistacia lentiscus L. seedlings afforested in a degraded semiarid soil. Soil Biology and Biochemistry, 34, 1139-1145.

Cardinale M, Brusetti L, Quatrini P, Borin S, Puglia AM, Rizzi A, Zanardini E, Sorlini C, Corselli C, Daffonchio D (2004) Comparison of different primer sets for use in automated ribosomal intergenic spacer analysis of complex bacterial communities. Applied and Environmental Microbiology, 70, 6147-6156.

Chazdon RL, Colwell RK, Denslow JS, Guariguata MR (1998) Statistical methods for estimating species richness of woody regeneration in primary and secondary rain forests of NE Costa Rica. In:Forest Biodiversity Research, Monitoring and Modeling: Conceptual Background and Old World Case Studie (eds Dallmeier F, Comiskey JA). pp. 285-309, Parthenon Publishing, Paris.

Chen H, Li B, Fang C, Chen J, Wu J (2007) Exotic plant influences soil nematode communities through litter input. Soil Biology and Biochemistry, 39, 1782-1793.

Clarke KR (1993) Non-parametric multivariate analyses of changes in community structure. Australian Journal of Ecology, 18, 117-143.

Colwell RK, Coddington JA (1995) Estimating terrestrial biodiversity through extrapolation. In:Biodiversity Measurement and Estimatio (ed Hawkesworth DL). pp. 101118, Chapman and Hall, London.

Cornelissen S, Botha A, Conradie WJ, Wolfaardt GM (2003) Shifts in community composition provide a mechanism for maintenance of activity of soil yeasts in the presence of elevated copper levels. Canadian Journal of Microbiology, 49, 425-432.

Coutinho HLC, Oliveira VM, Lovato A, Maia AHN, Manfio GP (1999) Evaluation of the diversity of rhizobia in Brazilian agricultural soils cultivated with soybeans. Applied Soil Ecology, 3, 159-167.

Cowling RM (1992) The Ecology of Fynbos: Nutrients, Fire, and Diversity. Oxford University Press, Cape Town.

Cowling RM, Hilton-Taylor C (1997) Phytogeography, flora and endemism. In:Vegetation of Southern Afric (eds Cowling RM, Richardson DM, Pierce SM). pp. 43-61, Cambridge University Press, UK.

Cowling RM, Pressey RL, Rouget M, Lombard A (2003) A conservation plan for a global biodiversity hotspot-the Cape Floristic Region, South Africa. Biological Conservation, 112, 191-216.

Danovaro R, Luna GM, Dell'Anno A, Pietrangeli B (2006) Comparison of two fingerprinting techniques, terminal restriction fragment length polymorphism and automated ribosomal intergenic spacer analysis, for determination of bacterial diversity in aquatic environments. Applied and Environmental Microbiology, 72, 5982-5989.

Deacon HJ, Hendey QB, Lambrechts JJN (1983) Fynbos Palaeoecology: A Preliminary Synthesis. National Scientific Programmes Unit: CSIR, pp 227. SANSP Report 75.

Dunbar J, Barns SM, Ticknor LO, Kuske CR (2002) Empirical and theoretical bacterial diversity in four Arizona soils. Applied and Environmental Microbiology, 68, 3035-3045.

Ehrenfeld JG, Ravit B, Elgersma K (2005) Feedback in the plant-soil system. Annual Review of Environment and Resources, 30, 75-115.

Fisher MM, Triplett EW (1999) Automated approach for ribosomal intergenic spacer analysis of microbial diversity and its application to freshwater bacterial communities. Applied and Environmental Microbiology, 65, 4630-4636.

Fomsgaard IS, Kristensen K (1999) Influence of microbial activity, organic carbon content, soil texture and soil depth on mineralisation rates of low concentrations of $14 \mathrm{C}$ mecoprop - development of a predictive model. Ecological Modelling, 122, 45-68.

Gaur AC, Misra KC (1978) Dynamics of microbial population in soil as influenced by simazine and ecological factors. Zentralblatt fuer Bakteriologie Parasitenkunde Infektionskrankheiten 
und Hygiene Zweite Naturwissenschaftliche Abteilung Mikrobiologie der Landwirtschaft der Technologie und des Umweltschutzes, 133, 357-361.

Goldblatt P, Manning JC (2000) Cape Plants: A Conspectus of the Cape Flora of South Africa. National Botanical Institute, Kirstenbosch and Missouri Botanical Garden Press, St Louis.

Green JL, Holmes AJ, Westoby M, Oliver I, Briscoe D, Dangerfield M (2004) Spatial scaling of microbial eukaryote diversity. Nature, 432, 747-750.

Gürtler V, Stanisich VA (1996) New approaches to typing and identification of bacteria using the 16S-23S rDNA spacer region. Microbiology, 142, 3-16.

Hamilton EW, Frank DA (2001) Can plants stimulate soil microbes and their own nutrient supply? Evidence from a grazing tolerant grass. Ecology, 82, 2397-2402.

Hättenschwiler S, Tiunov AV, Scheu S (2005) Biodiversity and litter decomposition in terrestrial ecosystems. Annual Review of Ecology and Systematics, 36, 191-218.

Hawksworth DL (2001) The magnitude of fungal diversity: the 1.5 million species estimate revisited. Mycological Research, 105, 1422-1432.

Heijnis CE, Lombard AT, Cowling RM, Desmet PG (1999) Picking up the pieces: a biosphere reserve framework for a fragmented landscape-the coastal lowlands of the Western Cape. Biodiversity and Conservation, 8, 471-496.

Hewson I, Winget DM, Williamson KE, Fuhrman JA, Wommack KE (2006) Viral and bacterial assemblage covariance in oligotrophic waters of the West Florida Shelf (Gulf of Mexico). Journal of the Marine Biological Association of the United Kingdom, 86, 591-603.

Jaccard P (1912) The distribution of flora in the alpine zone. New Phytologist, 11, 37-50.

Jessup CM, Kassen R, Forde SE, Kerr B, Buckling A, Rainey PB, Bohannan BJ (2004) Big questions, small worlds: microbial model systems in ecology. Trends in Ecology and Evolution, 19, 189-197.

Jonasson S, Michelsen A, Schmidt IK (1999) Coupling of nutrient cycling and carbon dynamics in the Arctic, integration of soil microbial and plant processes. Applied Soil Ecology, 11, 135-146.

Kemper J, Cowling RM, Richardson DM (1999) Fragmentation of South African renosterveld shrublands: effects on plant community structure and conservation implications. Biological Conservation, 90, 103-111.

Kongor RY (2009) Plant response to habitat fragmentation: clues from species and functional diversity in three Cape lowland vegetation types of South Africa, PhD Dissertation. University of Stellenbosch, Matieland, South Africa.

Kruger FJ (1979) South African Heathlands: Heathlands and Related Shrublands of the World, A Descriptive Study. Elsevier, Amsterdam.

Lipson DA, Schmidt SK, Monson RK (1999) Links between microbial population dynamics and nitrogen availability in an alpine ecosystem. Ecology, 80, 1623-1631.

Liu Y, Zhang T, Fang HHP (2005) Microbial community analysis and performance of a phosphate-removing activated sludge. Bioresource Technology, 96, 1205-1214.

Low AB (1983) Phytomass and major nutrient pools in an 11year post-fire coastal fynbos community. South African Journal of Botany, 2, 98-104.
Low AB, Bristow JW (1983) X-ray fluorescence spectrometry: A useful tool in the chemical characterization of soils. South African Journal of Science, 79, 52-55.

Low AB, Rebelo AG (1996) Vegetation of South Africa, Lesotho and Swaziland. Department of Enivromental Affairs and Tourism, Pretoria, South Africa.

Lozupone CA, Knight R (2007) Global patterns in bacterial diversity. Proceedings of the National Academy of Sciences of the United States of America, 104, 11436-11440.

Marchant JW, Moore AE (1978) Geochemistry of the Table Mountain Group. 2. Analysis of two suites of Western Graafwater rocks. Transactions of the Geological Society of South Africa, 81, 353-357.

Mena JL, Vásquez-Domínguez E (2005) Species turnover on elevational gradients in small rodents. Global Ecology and Biogeography, 14, 539-547.

Mitchell DT, Brown G, Jongens-Roberts SM (1984) Variation of forms of phosphorus in the sandy soils of coastal fynbos, south-western Cape. Journal of Ecology, 72, 575-584.

Mucina L, Rutherford MC (2006) The Vegetation of South Africa Lesotho and Swaziland. Strelitzia 19, South African National Biodiversity Institute, Pretoria.

Nüsslein K, Tiedje JM (1999) Soil bacterial community shift correlated with change from forest to pasture vegetation in a tropical soil. Applied and Environmental Microbiology, 65, 36223626.

Peay KG, Bruns TD, Kennedy PG, Bergemann SE, Garbelotto M (2007) A strong species-area relationship for eukaryotic soil microbes: island size matters for ectomycorrhizal fungi. Ecology Letters, 10, 470-480.

Ramette A, Tiedje JM (2006) Multi-scale responses of microbial life to spatial distance and environmental heterogeneity in a patchy ecosystem. Proceedings of the National Academy of Science, 104, 2761-2766.

Rebelo AG, Boucher C, Helme N, Mucina L, Rutherford MC (2006) Fynbos biome. In: The Vegetation of South Africa, Lesotho and Swaziland (eds Mucina L, Rutherford M) Strelitzia 19. South African National Biodiversity Institute, Pretoria, South Africa.

Rebelo AG (1992) Preservation of biotic diversity. In:The Ecology of Fynbos. Nutrients, Fire and Diversit (ed Cowling RM). pp. 309-344, Oxford University Press, Cape Town.

Reynolds HL, Packer A, Bever JD, Clay K (2003) Grassroots ecology: plant-microbe-soil interactions as drivers of plant community structure and dynamics. Ecology, 84, 2281-2291.

Richards MB, Stock WD, Cowling RM (1997) Soil nutrient dynamics and community boundaries in the Fynbos vegetation of South Africa. Plant Ecology, 130, 143-153.

Rouget M, Richardson DM, Cowling RM (2003) The current configuration of protected areas in the Cape Floristic Region-reservation bias and representation of biodiversity patterns and processes. Biological Conservation, 112, 129-145.

Rouget M, Jonas Z, Cowling RM, Desmet PG, Driver A, Mohamed M, Mucina L, Rutherford MC, Powrie LW (2006) Ecosystem status and protection levels of vegetation types. In:The Vegetation of South Africa, Lesotho and Swazilan (eds Mucina L, Rutherford MC). pp. 725-737, SANBI, Pretoria.

Saetre P, Bååth E (2000) Spatial variation and patterns of soil microbial community structure in a mixed spruce-birch stand. Soil Biology and Biochemistry, 32, 909-917. 
Slabbert E (2008) Microbial diversity of soils of the Sand fynbos, M.Sc. Thesis. University of Stellenbosch, Matieland, South Africa.

Smalla K, Wieland G, Buchner A, Zock A, Parzy J, Kaiser S, Roskot N, Heuer H, Berg G (2001) Bulk and rhizosphere soil bacterial communities studied by denaturing gradient gel electrophoresis: plant-dependent enrichment and seasonal shifts revealed. Applied and Environmental Microbiology, 67, 4742-4751.

Sokal RR, Rohlf FJ (1981) Biometry, 2nd edn. Freeman \& Company, San Francisco.

Spriggs AC, Stock WD, Dakora FD (2003) Influence of mycorrhizal associations on foliar $\delta 15 \mathrm{~N}$ values of legume and non-legume shrubs and trees in the fynbos of South Africa: Implications for estimating N2 fixation using the $15 \mathrm{~N}$ natural abundance method. Plant and Soil, 255, 495-502.

Stafford WHL, Baker GC, Brown SA, Burton SG, Cowan DA (2005) Bacterial diversity in the rhizosphere of Proteaceae species. Environmental Microbiology, 7, 1755-1768.

Stohlgren TJ, Falkner MB, Schell LD (1995) A modifiedWhittaker nested vegetation sampling method. Vegetation, 117, 113-121.

Tangjang S, Arunachalam K, Arunachalam A, Shukla AK (2009) Microbial population dynamics of soil under traditional agroforestry systems in Northeast India. Research Journal of Soil Biology, 1, 1-7.

Torsvik V, Goksøyr J, Daae FL (1990) High diversity in DNA of soil bacteria. Applied and Environmental Microbiology, 56, 782-787.

Torzilli AP, Sikaroodi M, Chalkley D, Gillevet PM (2006) A comparison of fungal communities from four salt marsh plants using automated ribosomal intergenic spacer analysis (ARISA). Mycologia, 98, 690-698.

Turrión MB, Glaser B, Zech W (2002) Effects of deforestation on contents and distribution of amino sugars within particlesize fractions of mountain soils. Biology and Fertility of Soils, 35, 49-53.

Ugland KI, Gray JS, Ellingsen KE (2003) The speciesaccumulation curve and estimation of species richness. Journal of Animal Ecology, 72, 888-897.

Unterseher M, Tal O (2006) Influence of small scale conditions on the diversity of wood decay fungi in a temperate, mixed deciduous forest canopy. Mycological Research, 110, 169-178.

White TM, Bruns T, Lee S, Taylor J (1990) Amplification and direct sequencing of fungal ribosomal RNA for phylogenetics. In:PCR Protocols: A Guide to Methods and Application (eds Innis MA, Gelfand DH, Sninsky JJ, White TJ). pp. 315-321, California Academic Press, San Diego.

Whittaker RH (1972) Evolution and measurement of species diversity. Taxon, 21, 213-251.

Witkowski ETF, Mitchell DT (1987) Variations in soil phosphorus in the fynbos biome. South African Journal of Ecology, 75, 1159-1171.

Xiao H, Zheng X (2001) Effects of plant diversity on soil microbes. Soil and Environmental Science, 3, 238-241.

Zhou J, Kang S, Schadt CW, Garten Jr CT (2008) Spatial scaling of functional gene diversity across various microbial taxa. Proceedings of the National Academy of Sciences of the United States of America, 105, 7768-7773.
Zhou J, Xia B, Treves DS, Wu LY, Marsh TL, O'Neill RV, Palumbo AV, Tiedje JM (2002) Spatial and resource factors influencing high microbial diversity in soil. Applied and Environmental Microbial, 68, 326-334.

E.S. is a PhD student at the Department of Microbiology, Stellenbosch University, South Africa. His work currently focuses on the soil microbial community structure and processes in Fynbos ecosystems. R.Y.K. studied plant responses to habitat fragmentation during his PhD at the Department of Conservation Ecology and Entomology, Stellenbosch University, South Africa. He looked at species and functional diversity in the Cape lowland vegetation of South Africa. K.E. is a Professor in Conservation Ecology at the Department of Conservation Ecology and Entomology and a core member of the Centre for Invasion Biology at Stellenbosch University, South Africa. Her research aims to understand the population and community ecology of semi-arid and riparian vegetation. K.J. is a Professor in Microbiology at the Department of Microbiology, Stellenbosch University, South Africa. She is a microbial ecologist that specialises in taxonomy of ascomycetes fungi and the role that these organisms play in the environment. The main theme of her research focuses on the diversity and structure of microbial communities in particularly Fynbos areas.

\section{Supporting information}

Additional supporting information may be found in the online version of this article.

Fig. S1 Agarose gel electrophoreses total extracted DNA from Riverlands on Feb 2007. Lanes 1 and 14: Hyper Ladder I, Lanes 2-5: Riverlands plot1A-D, Lanes 6-9: Riverlands plot A-D, Lane 10-13: Riverlands plot A-D PCR amplification.

Figs S2 and S3 Agarose gel electrophoreses of PCR amplification of total extracted DNA from Riverlands on Feb 2007 with fungal specific primer set ITS5 (FAM) and ITS4 and bacterial specific primer set ITSF (FAM) and ITSR. Lanes 1 and 14: Hyper Ladder I, Lanes 2-5: Riverlands plot1A-D, Lanes 6-9: Riverlands plot A-D, Lanes 10-13: Riverlands plot A-D PCR amplification

Fig. S4 The number of bacterial and fungal OTU's detected in each plot during February, April, June and September 2007.

Fig. S5 Comparative Shannon-Weaver diversity between fungi and bacteria for February, April, June and September 2007.

Fig. S6 The accumulation curves of bacterial operational taxonomic units for June 2007.

Fig. S7 The accumulation curves of fungal operational taxonomic units.

Please note: Wiley-Blackwell are not responsible for the content or functionality of any supporting information supplied by the authors. Any queries (other than missing material) should be directed to the corresponding author for the article. 